$\xi=-1$

\title{
Urban Green Zones Planning Concept and Ecological Functionality (Through the Example of Poltava, Ukraine)
}

\author{
Natalia Smoliar ${ }^{1}$, Viktor Bredun ${ }^{2}$, Olha Toronchenko ${ }^{3}$ \\ ${ }^{I}$ Poltava National Technical Yuri Kondratyuk University, Ukraine \\ ${ }^{2}$ Poltava National Technical Yuri Kondratyuk University, Ukraine \\ ${ }^{3}$ Poltava National Technical Yuri Kondratyuk University, Ukraine \\ Corresponding Author E-Mail:Smolarnat@Ukr.Net
}

\begin{abstract}
In the article major peculiarities and problems in architectural and planning decisions concerning Poltava urban greening are represented, and ways of solving them are suggested. The town's green zones appropriation, their ecological, town-planning, sanitary and hygienic, recreational, and in case of some of them nature-sanctuary importance is considered. Structure and economical constituents of Poltava urban green zones planning, which represents average town urban ecosystems in the central (forest-steppe) zone of Ukraine, is analyzed. Maps and figures depicting typical schemes of manufacturing, transportation structure, density of population and urban greening are provided. Outraging of acceptable concentrations in dust and formaldehyde while analyzing urban atmospheric air pollution level according to the data obtained from stationary sites, is shown. These proves importance of taking into account consideration of interdependence between levels and locating of town's natural resources polluting sources, first of all atmospheric air, with urban territory greening planned decisions. Based on materials concerning study of green zones ecological functionality effectiveness peculiarities, the concept of Poltava urban green zones planning is suggested. Modern town architectural and planning decisions ecological aspects should be integrated into local strategies and development programs, town general lay-outs, transportation systems planning, strategy referring environmental protection, and require local self-government and state support.
\end{abstract}

Keywords: green zone, landscaped area, ecological functionality, town, planning, Poltava.

\section{Introduction}

Modern urbanization processes significantly change people's lifestyle, transform the landscapes and lead to negative ecological changes. In accordance with World Health Organization (WHO) reports on town planning issues and environmental protection and health (2010) [18], green zones can have positive influence on physical activity, social and psychological well-being, air quality improvement and noise level decrease [6,16]. Green zones proper planning under urban conditions enables solving such social health problems as obesity, cardiovascular diseases, mental health and well-being [17].

In such context urban green zones become one of the indicators of town's steady development and thus perform a range of important factors: ecological, social, economic, esthetic, recreational, townplanning and climate-controlling [11].

Town's green zones integrated condition directly influences urban environment ecological security. A lot of countries worldwide pay considerable attention to town territories planning, preserving and maintenance as an integral part of urban development. That is why their condition optimization based on ecological functionality planning results is an important factor of urban settlements steady development.

\section{General problem formulation}

Green planting performs especially diverse and important functions. They play a crucial role in town building projects, they are towns' ecological development indicators, and they as well perform esthetic and recreational functions.

Green zones ecological role within a present days town can be rather significant depending on their quantitative and qualitative characteristics. First of all, green planting reduce heat island effect. Parks are usually characterized by lower temperature comparing to nearby territories. In park centre temperature is lower than in the outskirts, night temperature can reach $7^{\circ} \mathrm{C}$. Air cooling effect gets particular importance for preserving people's health while temperatures considerable increase. Reduction in energy usage for houses and buildings cooling also has ecological and economic importance, thus trees lessen wind speed and can have economic influence due to decrease in nearby houses heating [3]. Most notably it concerns summer and winter evergreen trees. Green planting reduce air pollution $[3,8,10]$. Photosynthesis results in green planting reducing $\mathrm{CO}_{2}$ level and increase oxygen concentration. Scientists [3,8] emphasize importance of indirect way of reducing $\mathrm{CO}_{2}$ level by means of cooling nearby houses in summer and decreasing energy usage. As a result solid air parcels resuspended into atmosphere are washed off with precipitations and fall into the ground along with fallen leaves. 
Green planting consume around $95 \%$ of ultraviolet solar radiation reducing cancroids carcinogenesis risk as well as cataract development [3].

Environment constituents size, color and spatial structure create human general state though the work of visual analyzer. Natural visual environments by contrast with technogenic one meets sight physiological forms. That is why being is green zones positively influence human psychophysical condition.

Green planting in town reduces noise pollution levels, in particular it relates to planting trees with spreading crowns and high dense bushes which due to evaporation increase air humidity in town, contribute to absorbing rainfall run-off.

Some sorts, forms and types of urban green planting dendroflora have antibacterial, bacteriostatic, fungicidal and antivirus properties by virtue of producing volatile fractions, oils, called volatile productions (phytoncids).

Considering green plants space role and their producing of primary products (foodchains supplying) as well as their environment creating role (create ecological niches for other living organisms - animals, fungi, lichens etc.), green plantings perform function of biodiversity and nature landscapes preserving in a modern town $[3,8]$. All these green zones functions determine their exceptional ecological meaning and obligation of taking them into account while developing and optimizing region's steady development program $[9,14]$.

One of important aspects of green area planning aspects is considering urban atmospheric air pollution level. Gardens and parks form airstreams which shift polluting wastes from mobile sources. Large concrete solid-web structure constructions restricting air circulation lead to rise in polluting wastes circulation that does not disperse. Because of this alongside the parking zones there should not be vast abutting buildings [10] According to the data [2], city forest reduces concentration of ozone $\left(\mathrm{O}_{3}\right)$, nitrogen dioxide $\left(\mathrm{NO}_{2}\right)$, sulfur dioxin $\left(\mathrm{SO}_{2}\right)$, carbon monoxide (CO), solids are less than 10 micron. Scientists estimate related ecological profit by more than million Euros per year.

In accordance with the data [7], green infrastructure can reduce solids level 2,5 (fraction 2,5) by $9,0 \%$ under trees dispersible effect. At the same time in densely constructed town districts with poor green planting solid settings were less than $0,03 \%$. Other scientists show that increase in polluting wastes setting by means of green planting can reduce $\mathrm{NO}_{2}$ concentration by $40 \%$ and solids by $60 \%$ [15].

Results of real estate analysis testify to green planting social and economic importance growth of in a town, and people's realizing their ecological value and attractiveness. They prove that price of apartments in parking zone can be by $2-4$ times higher per a public garden meter when compared to a nalogues in town districts with less green planting.

Though, not in all towns green zone area index meets town planning requirements. That is why in our research we tried to comprehensively reveal green zones importance in the modern town and to make analysis of Poltava landscaped areas ecological functionality and planning concept that represents urban average towns ecosystems in central (forest-steep) zone of Ukraine [13].

\section{Research results discussion}

Modern town is an urban ecosystem, considerable component of which is green planting. As a rule they are represented by tree, shrub and grassland vegetation cultivated in esthetically valuable combinations, which create favorable conditions for life sustenance in urban ecosystem. To enable green planting effective performing their functions on oxygen aerification, environment wash-out from dust and chemical pollutants, noise reduction and regulation of micro climate and recreation, relevant town planning rules and principles for green constructing performing should be followed. Fundamental issues of the Law of Ukraine "On approval of the rules for the maintenance of green planting in the settlements of Ukraine" adopted by the Cabinet of Ministers of
Ukraine in 2006 are directed to realization of these ecologically, socially and economically, sanitary and hygienically important objectives. Despite of this, its key issues and principles are often neglected in a town that leads to worsening in towns' population's health, impoverish biodiversity, deteriorates ecological situation in general, and in future can lead to even more serious ecological consequences.

Under existing and supposed by general urban greening (green zone) lay-out system, all three groups of green areas are to be available, which are defined by functional feature, namely:

- those of general use - parks, public gardens, avenues, forests, forest parks, hydro parks, greenland parks;

those of limited use - plantings on the territories of residential and public buildings, schools, children locations, manufacturing enterprises, sport buildings, health care institutions;

- those of special use - plantings along the streets, in sanitaryprotective and protective zones, sanitary protective zones, at the territories of cemetery, botanic gardens, zoos.

Town territory planting system from one hand can be defined by town division into planning elements, on the other - to determine town planning structure. While creating green planting system factors to take into account should include the town's size and functional profile, physical and geographical location, climate conditions in particular (volume of precipitations, air temperature, winds, water reservoirs and rivers availability).

Considering micro climate, ecological and social importance of green plantings and relating green areas to construction and population density, urban planting norm should be $40-50 \%$ of habitable area which will ensure possibility to have $40-50 \mathrm{~m}^{2}$ per citizen [12].

While planning green zones in urban conditions, demographical data and aging peculiarities as well as population needs should be taken into account [17]. Thus, youth population groups are more interested in parks and town gardens for active rest, creative ideas realization and social events organizing. Married couples require playgrounds to have rest with children; elderly people are in want of availability of structures for special needs.

Green planting system should correspond to town planning structure. Every single planning unit should be correspondent to certain green plants; housing block - housing block garden; residential area - residential area garden, avenue, public garden; planning area - town parks, gardens, children's and sport parks, hydro parks, forest parks, avenues, public gardens, riverwalks.

Green planting system structure depends also on town size. In this consideration green zones typification can be as follows: small town - the simplest structure: town parks, avenues, housing blocks gardens; average town - town park, residential area gardens, avenues, public gardens, housing blocks gardens; big city - city park, residential area gardens, children's and sport parks, hydro parks, forest parks, avenues, public gardens, housing blocks gardens etc. For Poltava region, under lack of big cities and metropolises, these issues are applicable for average (Poltava (town of regional significance), Kremenchuk, Lubny, Myrhorod, Horishni Plavni) and partly for small ones, majority of which are towns and urban-type settlements.

According to results of green planting location analysis in Poltava, certain peculiarities can be distinguished: parks and public gardens are located in the central part of the town, forest type green plantings of natural origin are situated in its suburbs; available riverside zones along the rivers (Vorskla and Kolomak) require scientifically grounded landscape and recreational arrangements including preserving of nature type areas.

Poltava is the biggest town in the region by territory ( 1 thousand $\mathrm{km}^{2}$ ) and by population (310 thousand people). Regarding green planting amount and condition Poltava is considered to be a green and ecologically favorable place [4,5]. Placement of green plantings as urban green zone structural elements is depicted at Figure 1 .

The following elements of green planting system are defined for Poltava. Town parks (the most common type of the park), where rest in natural environment is combined with entertainment events. 
There are totally 19 such objects in the territory of Poltava. They are predominantly small by size (up to 25 hectares) and one of average size (124,5 hectares). They are located in the central (historical) part of the town within the limits of comfortable

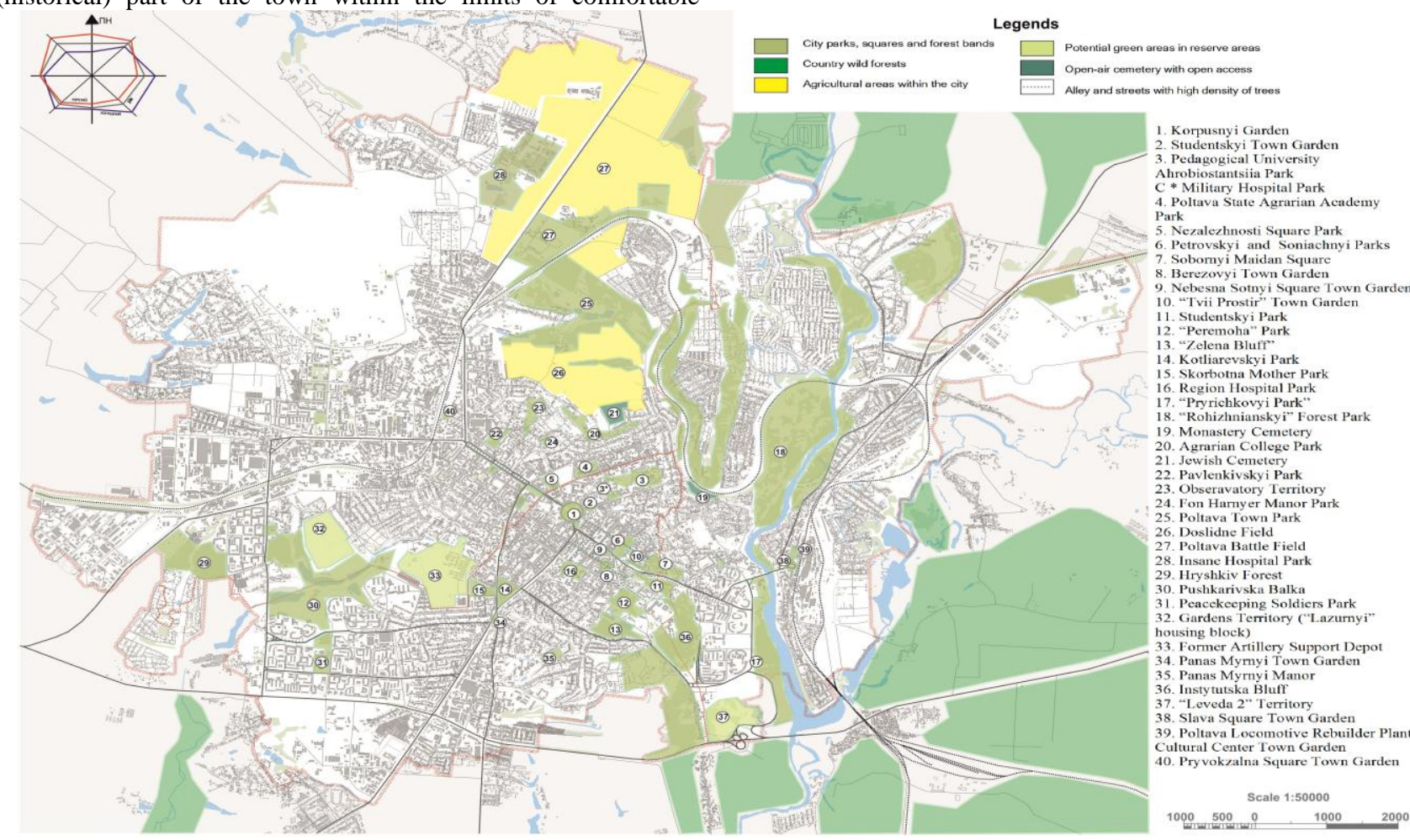

Fig.1 Green plantings for general use (town parks, public gardens, avenues) transport connections and attending them by local population and non-resident vacationers.
Poltava public gardens (eight objects) are used for short-time rest and artistic and decorative composition of town squares, streets, common buildings and monuments. Their size is equal to 1-2 hectares. As usual, the main decoration element is central site with a sculpture, fountain or pool. The main of them are "Slava Square Town Garden", "Pryvokzalna Square Town Garden", "Sobornyi Maidan Square", "Studentskyi Square".

Avenues are supposed for pedestrian flow, having a walk or short rest. They are usually arranged in major highways or in public centers under pedestrians intensive flow. Avenues are places between street traffic ways and pavements, or along the town center. Their width is usually equal to 10-50 meters, which defines the special aspects of their planning decisions concerning amount and width of alleys, planting specifics and landscaping.

Other elements of general use zones (children's parks for games, entertainment, physical training and cultural and educational events; hydro parks and greenland parks arranged in areas of rivers, lakes and water reservoirs for common rest; forest parks) in Poltava are not available, though there are potential abilities for creating some of them (for instance "Pryrichkovyi Park", promising objects in Levada and Ohnivka housing blocks etc.)

Green planting of special use includes botanic gardens, zoos, green planting in sanitary-protective and protective zones, at the territories of cemeteries, major highways and residential streets, seed-plots and flowering farms.

These green zones structural elements analysis testifies low level of their arrangements, their unavailability in the places of obligatory creating, not taking into account while planning new town housing blocks construction (for instance Sady-1, Sady-2, Ohnivka-1, Ohnivka-2) and redeveloping existing ones (Polovky, Brailky, HRL, Bozhenka). Under modern social and economic conditions these elements reconstruction is often limited to their full destruction due to construction widening or appropriation change, though green planting of sanitary-protective zones alongside railways and motorways are often intended for snowing mound protection and roads decoration as well as for habitual area protection from industrial objects harmful impact. Due to the fact that Poltava lies at the crossroad of many motor ways, including motorway of international significance (M-03 Kyiv Dovzhanskyi goes through the town as well as railroads (there are two railway stations in the town (Poltava-Pivdenna, PoltavaKyivska), efforts should be directed to creating and optimizing these green zone structural elements.

Poltava also lacks such green zone structural elements as botanic gardens and zoos.

Botanic gardens are intended for scientific and research, cultural and educational works and people popular rest. They are located far from industrial areas, noise sources, they protect from strong winds. Variety of land forms and water reservoirs availability is also desirable. $50-70 \%$ of their territory should occupy botanic expositions zone.

Nowadays such an object according to its functional relevance and arrangement is park and park art monument of local significance "Pedagogical University Ahrobiostantsiia Park", at the basis of which is is possible to create town botanic garden with further assignment to it conservation status.

Considering town landscapes inhomogenuity and variety, availability of water reservoirs and feasibility of creating artificial hydraulic structures, in particular at the territories of new town housing blocks construction (for example Ohnivka-1 and Ohnivka-2), constructing a zoo aimed at scientific and research works performing, cultural and educational activity organizing and harmonized popular rest of vacationers with principal zones suggested (recommendation and expositional - 50-70\%; rest and entertainment $-25-35 \%$, scientific and research $-25-35 \%$ and household $-2-5 \%$ of the territory).

Green planting at the highway and residential streets are intended for noise protection, pavements shadowing in summer time, streets decoration. In the territory of modern Poltava they are preserved at a few historical center streets, at many others they are constantly under reconstruction because of road construction works, insufficient trees condition (mainly due to white mistletoe infestation, mechanical damage, failure because of anti-icing mixtures containing salt and other undesirable for trees chemical 
elements) or destruction as a result of enterprises territories extending, roads or other constructions.

Seed-plots and flowering farms as structural elements of urban green zone are intended for growing transplants of trees and herblike ornamental plants. The biggest of the kind are situated in the suburbs of Poltava.

Green plantings are standardized per citizen. In Poltava this index is equal to $108 \mathrm{~m}^{2}$ per person with Central European $20 \mathrm{~m}^{2}$ that approves the town status as a "green" one.

Green plantings location at the town's territory is exceptionally unequal (fig.1). Majority of them are located in the central part of the town, minor part - in the suburbs, insufficient amount and its space is defined for industrial town area, for example Kyivskyi. In the territory of some of its housing blocks (Polovky, Brailky, HRL) there are only one-way side hedge roads and planted detached houses yards. There is a hazard phenomenon evident at present time: town residential areas modern construction is carried out without defining and arranging green zones structural elements which in turn will worsen general ecological situation in the town.

To analyze ecological situation in Poltava we have used maps of Poltava territory planting, density of population, location of industrial zones and major transportation corridors, placed at the local council official web-site (http://www.rada-poltava.gov.ua /city/plan/). We have also conducted analyses of the Department for Ecology and Natural Resources of Poltava regional council as for locating air condition stationary sites in the territory of Poltava and data according air pollution obtained at these sites in the period from June to September 2017. Air sampling was conducted by Derzhhidromet hydro meteorology Poltava center in a manner of air pollution systematic observation in accordance with standard full program daily (four times a day), excluding Sunday and holidays, at four "POST-2A".

By means of overlay operations in program environment of QGIS packet we have obtained complex analytical maps of factors correlation for urbanized town environment ecological quality creating. These maps combined with information on atmospheric air pollution level characterize impact of main anthropogenic factors (industry and transport) on air condition, town population share falling under these factors impact as for pollution neutralizing and renewing necessary level of atmospheric air condition (Fig. 2 - 4)

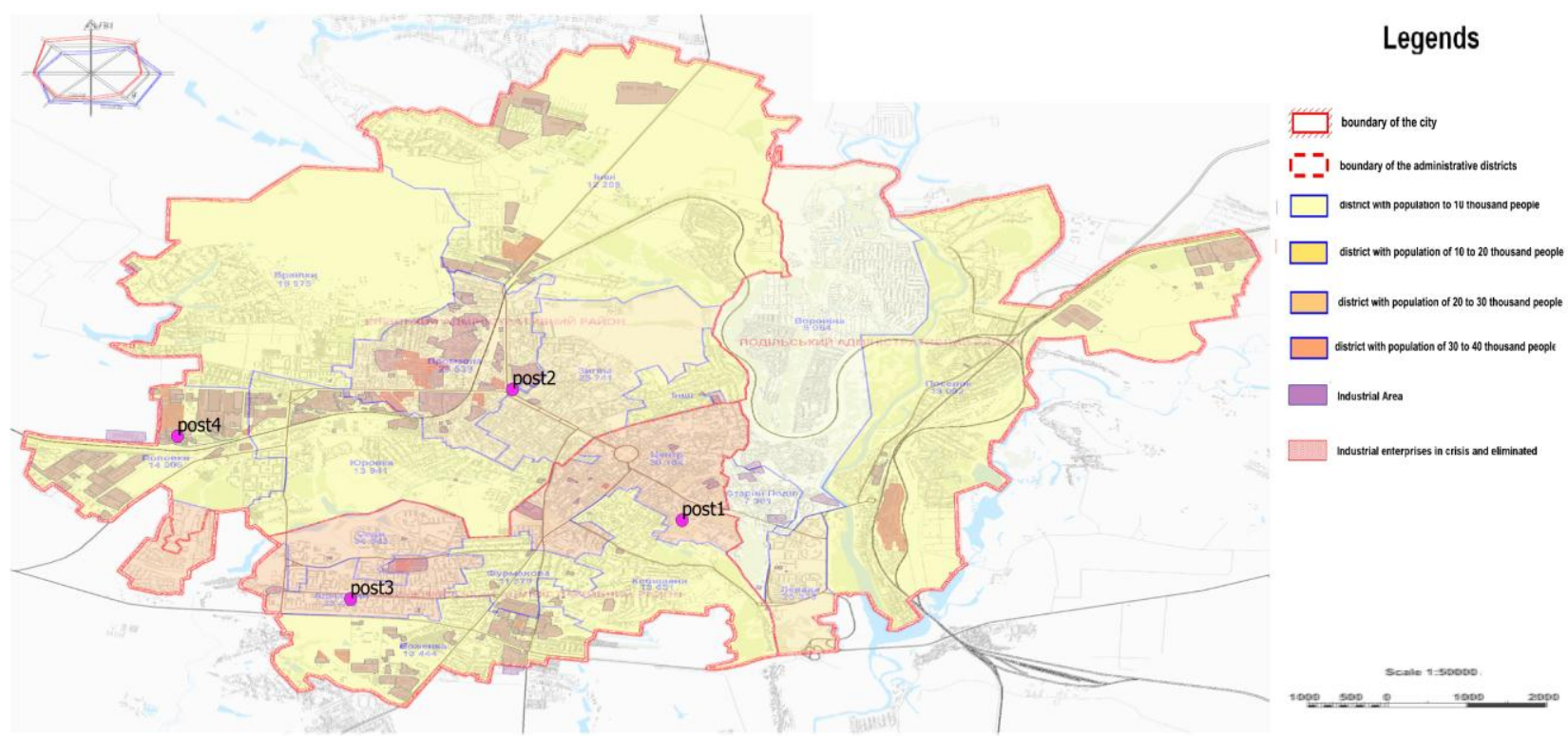

Fig. 2. Density of population and industrial zones concentration in the territory of Poltava

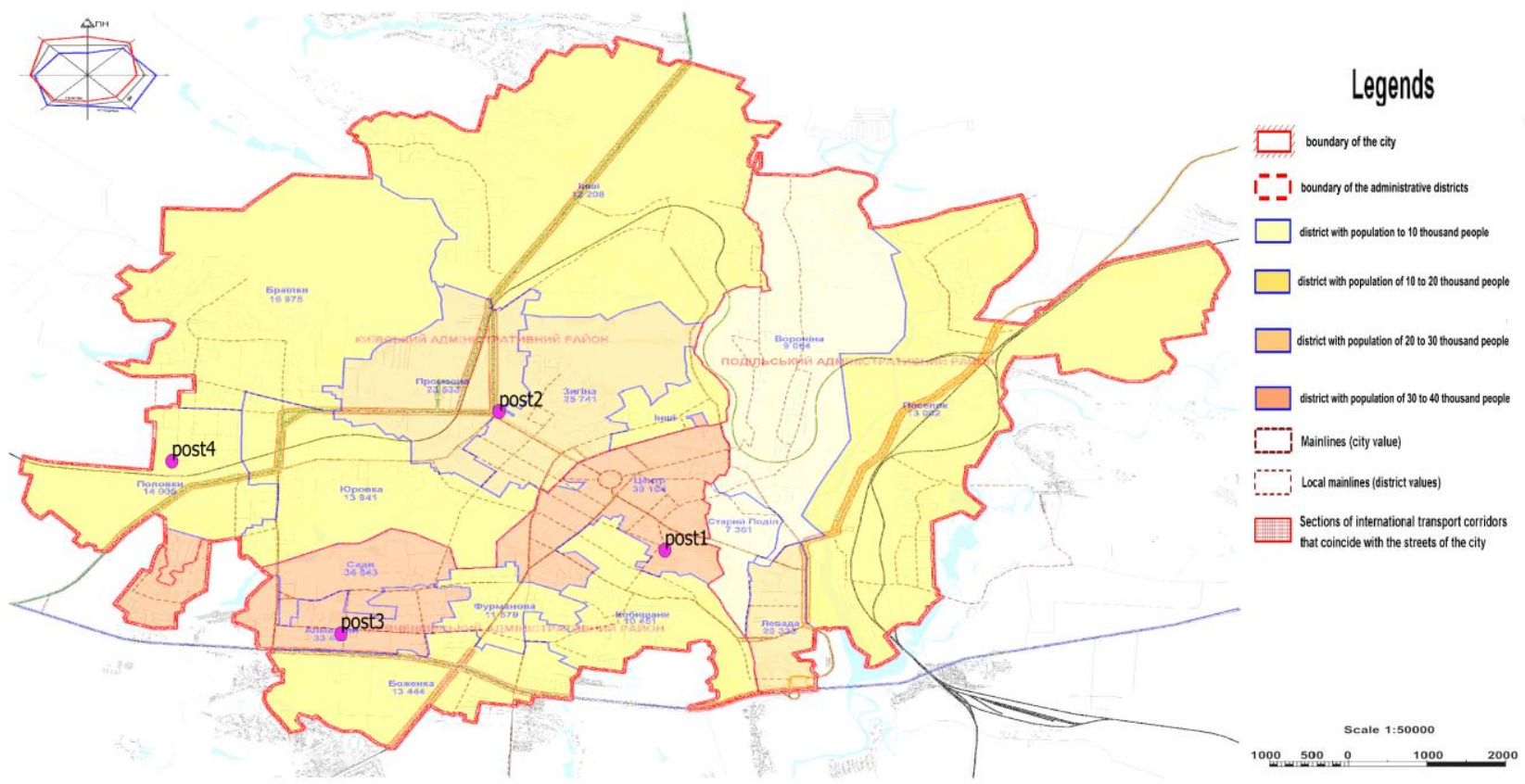

Fig. 3. Density of population and separate transport corridors location in the territory of Poltava 


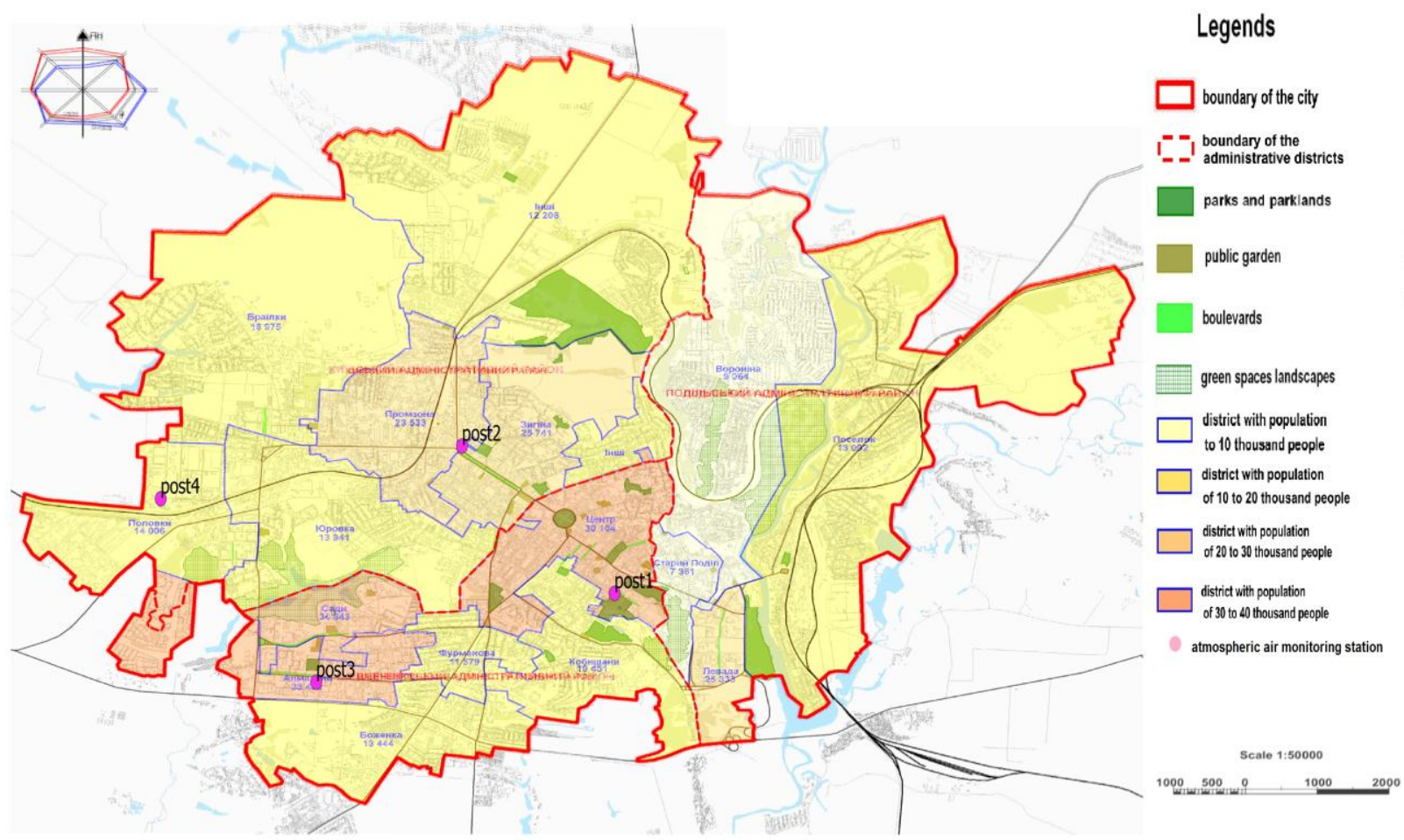

Fig. 4. Poltava population green zones provision

Table 1. Average harmful elements concentration indices in MAC shares at the stationary sites of Poltava in June-September 2017

\begin{tabular}{|c|c|c|c|c|c|c|c|c|c|c|c|c|c|c|c|c|}
\hline Month & \multicolumn{4}{|c|}{ June } & \multicolumn{4}{|c|}{ July } & \multicolumn{4}{|c|}{ August } & \multicolumn{4}{|c|}{ September } \\
\hline № of stationary site & 1 & 2 & 3 & 4 & 1 & 2 & 3 & 4 & 1 & 2 & 3 & 4 & 1 & 2 & 3 & 4 \\
\hline Nitrogen peroxide & 0,75 & 1 & 1 & 1 & 0,75 & 1,25 & 1,0 & 1,0 & 0,75 & 1,75 & 1,0 & 1,0 & 0,5 & 1,0 & 1,0 & 1,0 \\
\hline Carbonic oxide & 0,4 & 1,1 & 0,8 & 0,7 & 0,4 & 1,1 & 0,8 & 0,7 & 0,6 & 1,4 & 1,0 & 0,8 & 0,3 & 0,8 & 0,8 & 0,7 \\
\hline Formaldehyde & 1,3 & & 2,3 & 2,7 & 2,0 & & 2,3 & 2,7 & 2,7 & & 3,7 & 3,7 & 1,0 & & 2,3 & 2,3 \\
\hline
\end{tabular}

Table 1 represents average indices of harmful wastes concentration in marginally acceptable coefficients (MAC) shares per month at each of the sites. Data are given according to the elements which were MAC increased noticed in the months defined. Cartographic material analysis (fig.1-4) shows that the main territories with average density of population have the main anthropogenic impact. Altogether, in industrial areas of Poltava, areas of major transport corridors locations and the most densely populated town territories there is a deficit of green plantings (fig. $3)$. It significantly decreases living comfort level and negatively impacts the atmospheric air condition.

Data from stationary site №2 relating atmospheric air pollution with nitrogen peroxide, carbonic oxide and dust, and their correlation with data from stationary posts №3 and 4 prove that principal atmospheric air pollutant in Poltava is transiting and town transport (there is a tendency to increase in number of transport vehicles in terms of town motor ways low traffic capacity; motor vehicles movement in the town requires regulation organization). The most significant MAC exceedance is typical for dust and formaldehyde. As far as plants leaves surface is much cooler than pavement surface, cold dawn-droughts occur in green planting area causing dust settlement on the trees.

This proves importance of taking into account the levels interdependence and location of the town's natural resources pollution sources, first of all it is atmospheric air, with the town's green planting (special aspects of their placements, areas, graphical and specific structure etc.).

Let us note that approaches to green planting protection and using are chosen depending on their status and assignment. To our mind, green plantings cannot be viewed separately from the territories they are located at.

Considering mentioned above, provision of modern ecological life quality standards in terms of urbanized environment determines the necessity of ecological planning system improvement while creating the town long-term development plan, and the fist of them all is green planting graphic and specific structure optimization. Thus left-bank part of Poltava requires the biggest attention, in particular the areas of multistoried buildings. Some town areas constructed according to the last century townplanning and sanitary norms, in terms of modern anthropogenic loading require implementing of nonstandard landscape architecture and planning decisions. All of these are possible under realization of "Program on Development of Parks, Town Gardens and Avenues in Poltava 2018-2020" events, adopted by Poltava town council in December 22, 2017.

According to M.Nazaryk [11], green planting system in general should correspond to such principal tasks:

- functional organization of various assignments urban territories including those for people outdoor rest;

- sanitary and hygienic one which includes urban environment renewal and micro climate improvement;

- architectural and artful one which includes creating integral and architecturally distinguishing town landscape.

Main criteria for variant evaluating of territories greening system are:

- equality of their division within the town territory, in particular it concerns residential buildings, transport and pedestrian connectivity;

- system continuity that depends on gardens and parks planning connection feasibility by town gardens, riverwalks, planted trees and alleys;

- complex organizing of town internal and external planted territories, planning connection of town internal open spaces with suburban forest parks and forests.

In addition to these, in our mind, taking into account modern nature protecting concepts including preserving of trivial and landscape biodiversity, it is rightful to define one of the most important objectives suggested for modern urban green planting that is nature protection. In terms of existing and potential ecological risks and threats it is important to assess conservation 
(wildlife sanctuary) status to fiducial objects (structural green zones elements, both natural and artificially created and collector's) which perform important ecological, nature protecting, ecological and educational, historical and cultural functions. And according to criterion of urban green planting complex evaluation it is purposeful to add sozological one enabling urban green planting evaluation first of all as centers of preserving rare biota and objectively define their place in green zone structure under urban functional planning [1]. In Poltava such objects with well-preserved biodiversity include "Pryrichkovyi Park", "Rohiznianskyi Forest Park", "Hryshkiv Forest", "Pushkarivska Balka", "Instytutska Bluff" and others.

\section{Conclusions}

With the basis on materials concerning studying the peculiarities of green planting zones ecological functionality in Poltava the following conclusions can be made:

- the principal aim of green zones functioning is providing social and functional people needs in terms of preserving landscape and natural territory integrality, its extensional and regional distinctiveness;

- it is necessary to renew information referring inventorying (it is necessary to calculate the number of trees and shrubs according to their planting type, species and age) and certification of urban green zone planting (in Poltava such work is conducted only regarding separate green zone structural elements). Besides there is a long-standing need for new programs and projects creating for complex urban green zones development within town limits;

- one of primary objectives is green planting zones defining and surface making;

- Poltava green zones constituents require conducting effective and scientifically grounded reconstruction of existing and creating new objects in the territory of new housing blocks and extending the others;

- urban territories constructed under town-planning and sanitary rules of the last century in term of present days social and economic and anthropogenic loading require implementing nonstandard architectural and planning landscape decisions;

- industrial enterprises territory and main transport motor ways should be separated from Kyivskyi residential area by means of "green screens"; taking into account general high level of atmospheric air pollution in their territory these should include latifoliate trees resistant to urbanizes environment impact or ecologically steady invasive plants;

- to increase town's esthetic and social and recreational attractiveness, some housing blocks (Sady-1, Polovky, Brailky, HRL area) green zones can be reorganized into town gardens with artificial and natural water reservoirs;

- creating scientifically based conception of urban green zone developing and defining structural elements in the town general lay-out;

- to conduct reassigning of urban green planting functions considering the results of their complex assessment (having defined the objects priority functions and levels and types of anthropogenic loading as important conditions for their target using, maintenance, renewal and preserving);

- while conducting complex urban green planting assessment their nature-protecting significance should be taken into consideration, and to apply sozological criterion of their biodiversity with the aim of preserving their status of conservation object;

- to assess conservation status to some structural green zones elements that are fiducial objects of both natural and artificially origin considering their ecological and nature protective significance;

- modern town planting index adjusting to $40-50 \mathrm{~m}^{2}$ per citizen by means of urban green zone effective planning;
- while planning green zones in urban conditions, demographical data and aging peculiarities and needs of population should be taken into account;

- improving strategies and programs of urban green zone structural elements developing and effective (scientifically grounded, purposeful in terms usage, financially provided) realization of measures suggested by them.

As far as urban territories greening measures are long-term investments, they have to be integrated into local strategies and developmental frameworks, namely urban general lay-outs, steady development programs, transport systems planning, strategies referring protecting biodiversity and environment in general. All these needs local self-government support and realizing the fact that urban green planting issue goes beyond the limits of ecological or construction targets, providing social well-being, social health and increase in standard of life.

\section{References}

[1] Bairak O.M., Stetsiuk N.O., "Rol' zelenikh zon mist Poltavslo oblastiyak skladovykh regionalnoi ekomerezhi”, Zhyva Ukraina. Spetsvypusk "Rozmai" (2008), - pp. 15-16.

[2] Chaparro Lydia, Terradas Jaume, "Ecological Services of Urban Forest in Barcelona", Centre de Recerca Ecològica i Aplicacions Forestals Universitat Autònoma de Barcelona Bellaterra SPAIN, (2009)

[3] David J. Nowak, Gordon M. Heisler, "Air Quality Effects of Urban Trees and Parks", (2010).

[4] Dovkill'a Poltavshchyny / red. Yu.S. Golik, O.E. Ill'ash, Poltava, 2014, p. 72-82.

[5] Ekologichnyi atlas Poltavy / red. Yu.S. Golik, V.A. Baranovskyi, O.E. Ill'ash, Poltava, 2007, 128 p.

[6] Fifth M inisterial Conference on Environment and Health "Protecting children's health in a changing environmen", Parma, Italy, 10-12 March 2010.

[7] Jeanjeana A.P.R., Monksb P.S., Leigh R.J., "Modelling the effectiveness of urban trees and grass on PM2.5 reduction via dispersion and deposition at a city scale", Atmospheric Environment, Vol. 147 (December 2016), pp. 1-10.

[8] Heusinkvelt Benjamin, "Studying the Effect of Urbanization on Tree Growth Surrounding Streams in Lincoln, Nebraska" (2016). Environmental Studies Undergraduate Student Theses. 182.http://digitalcommons.unl.edu/envstudtheses/182

[9] Indeks ekologicheskoi efektivnosti, http://gtmarket.ru /ratings/environmental-performance-index/info

[10] Makhelouf A. "The effect of green spaces on urban climate and pollution", Iran. J. Environ. Health. Sci. Eng., Vol. 6, No. 1, (2009), pp. 35-40.

[11] Nazaruk M., Zhuk Yu. "Zeleni zony malykh i serednikh mist L'vivskoi oblasti: suchasnyi stan ta perspektyvy funktsionuvann'a", Fizychna geografia ta geomorfologia, Vip. 1, (2013), pp. 54-62.

[12] Rudenko A.Yu., Cherno V.S. Osnovy gigiyeny, 2010, 127 p.

[13] Natsional'nyi atlas Ukrainy, Kiev, 2007, 435 p.

[14] The 2016 Environmental Performance Index Report, http://www.epi.yale.edu

[15] Thomas A.M. Pugh, Robert MacKenzie A., Duncan Whyatt J., Nicholas Hewitt C., "Effectiveness of Green Infrastructure for Improvement of Air Quality in Urban Street Canyons", Environ. Sci. Technol., Vol. 46, No 14, (2012), pp. 7692-7699.

[16] Urban green spaces and health. Copenhagen: WHO Regional Office for Europe, 2016.

[17] Urban green space interventions and health a review of impacts and effectiveness. Copenhagen: WHO Regional Office for Europe, 2017.

[18] plobl-invest.gov.ua 